\title{
HUBUNGAN SIKAP PENJAMAH MAKANAN DENGAN HYGINE JAJANAN TRADISIONAL DI PASAR TRADISIONAL KOTA SIBOLGA TAHUN 2018
}

\author{
Irmawati Silalahi, Crishartanto Simanungkalit \\ Program Studi D-III Keperawatan STIKes Nauli Husada Sibolga \\ Email : crishartanto@yahoo.co.id
}

\begin{abstract}
Food handlers are people who are directly related to food and equipment ranging from the preparation, cleaning, processing, transportation to presentation. Personal hygiene and healthy behavior of food handlers must be considered. The general objective of this study was to determine the relationship of the attitude of food handlers with traditional snacks hygine in the traditional market of Sibolga City in 2018. This research is a quantitative study with a descriptive correlation design approach. The results were obtained by using Pearson correlation test to determine the relationship between the variables of food handlers attitude and hygiene hygiene obtained by Pearson Correlation. The results were $-0.396<0.05$, which means there is a relationship between the attitude of food handlers and sanitation hygiene. The results of the Pearson correlation test on the significance of the relationship between the variables of food handlers' attitudes and hygiene hygiene were obtained as a result of $0.041<0.05$ which means there is a relationship between the attitude of food handlers and hygiene hygiene. The level of relationship is in a moderate correlation and is in a negative relationship. It is recommended that this study be useful for education, and it is recommended that research be carried out with the same larger sample size and in different places, increasing the provision of information on the behavior of food handlers and hygines in traditional markets in the city of Sibolga
\end{abstract}

Keywords: Attitude of food handlers, hygine snacks, traditional, markets

\begin{abstract}
Abstrak
Penjamah makanan adalah orang yang secara langsung berhubungan dengan makanan dan peralatan mulai dari tahap persiapan, pembersihan, pengolahan, pengangkutan sampai dengan penyajian. Personal higiene dan perilaku sehat penjamah makanan harus diperhatikan. Tujuan umum penelitian ini adalah untuk mengetahui hubungan sikap penjamah makanan dengan hygine jajanan tradisional di pasar tradisional Kota Sibolga Tahun 2018. Penelitian ini merupakan penelitian kuantitatif dengan pendekatan desain deskriptif korelasi. Hasil penelitian didapat dengan menggunakan uji pearson corelation untuk mengetahui hubungan variabel sikap penjamah makanan dengan hygene sanitasi diperoleh Pearson Correlation diperoleh hasil adalah -0,369 < 0,05 artinya ada hubungan antara sikap penjamah makanan dengan hygene sanitasi. Hasil dari uji pearson corelation terhadap nilai signifikan hubungan variabel sikap penjamah makanan dengan hygene sanitasi diperoleh diperoleh hasil adalah $0,041<0,05$ artinya ada hubungan antara sikap penjamah makanan dengan hygene sanitasi. Tingkat hubungan berada pada korelasi sedang dan berada pada hubungan negatif. Disarankan agar Penelitian ini hendaknya berguna bagi pendidikan, dan disarankan dilakukan penelitian yang sama dengan jumlah sampel yang lebih besar dan di tempat yang berbeda, meningkatkan pemberian informasi mengenai perilaku penjamah makanan dan hygine di pasar tradisiona di kota sibolga.
\end{abstract}

Kata Kunci : Sikap Penjamah makanan, hygine jajanan, tradisional, pasar 


\section{PENDAHULUAN}

Di Indonesia berdasarkan asumsi bahwa $80 \%$ kejadian keracunan di sebabkan ditularkan melalui makanan. Hal ini di sebabkan oleh konstaminasi bakteri patogen. Penelitian ini bertujuan untuk mengetahui hubungan antara kondisi hygiene sanitasi tempat penjualan pecel dengan angka kuman Eschericha Coli. Kegiatan hygiene sanitasi makanan adalah salah satu upaya untuk menjamin kualitas makanan dari pencemaran selama proses pengolahannya Agar manakan sehat bagi konsumen diperlukan persyaratan khusus antara lain cara pengolahan yang memenuhi syarat, cara penyimpanan yang betul dan pengangkutan sesuai dengan ketentuan (Mukono, 2016).

Banyak orang yang sakit dan biasanya karena pola hidup mereka sendiri yang kurang baik dan kebiasaan yang kurang baik sehingga dapat melemahkan dan merusak tubuh. Perihal kesehatan cukup mudah untuk dipahami, akan tetapi masih banyak orang yang sakit karena kurangnya pengetahuan tentang arti kesehatan ataupun karena lalai. Dalam pelayanan segala kebutuhan yang diperlukan telah siap sedia, seperti pelayanan akomodasi, restoran, bar, fitness center, transportasi, dsb (Marianti, 2017).

Berdasarkan beberapa penelitian, penyebab beberapa kasus keracunan makanan diantaranya adalah bakteri Staphylococcus aureus, Vibrio cholera, E.coli dan Salmonella. Bakteri E.coli dan Staphylococcus aureus adalah salah satu bakteri indikator untuk menilai kualitas sanitasi makanan. Bakteri E.coli merupakan bakteri yang berasal dari kotoran hewan maupun manusia. Sedangkan sumber bakteri Staphylococcus aureus dapat berasal dari tangan, rongga hidung, mulut dan tenggorokan pekerja. Sekitar $70 \%$ kasus keracunan makanan di dunia disebabkan oleh makanan siap santap yaitu makanan yang sudah diolah, terutama oleh usaha katering, rumah makan, kantin, restoran maupun makanan jajanan (Fardiaz, 2017).

Badan Pusat Pengawasan Obat dan Makanan mencatat bahwa selama tahun 2004 di Indonesia telah terjadi 82 kasus keracunan makanan yang menyebabkan 6.500 korban sakit dan 29 orang meninggal dunia. Sebanyak $31 \%$ kasus keracunan itu disebabkan makanan yang berasal dari jas boga dan buatan rumah tangga (Antara, 2004). Data dari Badan
Pengawasan Obat dan Makanan (BPOM) Provinsi Gorontalo Tahun 2011 menemukan 8 sampel makanan jajanan tidak memenuhi syarat mutu dan keamanan pangan. Dimana pada makanan jajanan tradisional terdapat bakteri koliform.

Pendapat senada mengungkapkan bahwa bahwa sanitasi merupakan bagian penting dalam pengolahan pangan yang harus dilaksanakan dengan baik. Sanitasi dapat didefinisikan sebagai usaha pencegahan penyakit dengan cara menghilangkan atau mengatur faktor-faktor lingkungan yang berkaitan dengan rantai perpindahan penyakit tersebut (Purnawijayanti, 2001).

Penjamah makanan adalah orang yang secara langsung berhubungan dengan makanan dan peralatan mulai dari tahap persiapan, pembersihan, pengolahan, pengangkutan sampai dengan penyajian. Peran penjamah makanan sangat penting dan merupakan salah satu factor dalam penyediaan makanan/minuman yang memenuhi syarat kesehatan (Dewi, 2018).

Personal higiene dan perilaku sehat penjamah makanan harus diperhatikan. Seorang penjamah makanan harus beranggapan bahwa sanitasi makanan harus merupakan pandangan hidupnya serta menyadari akan pentingnya sanitasi makanan, higiene perorangan dan mempunyai kebiasaan bekerja, minat maupun perilaku sehat (WHO dan Depkes RI, 2014). Pemeliharaan kebersihan penjamah makanan, penanganan makanan secara higienis dan higiene perorangan dapat mengatasi masalah kontaminasi makanan.

$$
\text { Dengan demikian kebersiha }
$$

penjamah makanan adalah sangat penting untuk diperhatikan karena merupakan sumber potensial dalam mata rantai perpindahan bakteri ke dalam makanan sebagai penyebab penyakit (Anwar, 2015).

WHO (2016) menyebutkan penjamah makanan menjadi penyebab potensial terjadinya kontaminasi makanan apabila: 1) menderita penyakit tertentu; 2) kulit, tangan, jari-jari dan kuku banyak mengandung bakteri kemudian kontak dengan makanan; 3) apabila batuk, bersin maka akan menyebarkan bakteri; 4) akan menyebabkan kontaminasi silang apabila setelah memegang sesuatu kemudian menyajikan makanan; dan 5) memakai perhiasan (Jenie, 1996). Pengertian menurut 
KEPMENKES No. 1098 tentang Hygiene Rumah Makan dan Restoran, Penjamah makanan adalah orang yang secara langsung berhubungan dengan makanan dan peralatan mulai dari tahap persiapan, pembersihan, pengolahan, pengangkutan, sampai dengan penyajian. Untuk memperoleh kualitas makanan yang baik perlu diperhatikan dan diawasi mengenai pengetahuan, sikap dan perilaku tenaga pengolah (Depkes, 2013).

Menurut (Warsito, 2017), ada dua permasalahan pokok kejadian penyakit menular melalui makanan karena penjamah makanan, yaitu : 1. Bahwa timbulnya suatu penyakit menular melalui makanan kalau diselidiki umumnya bersumber pada tenaga pengolah makanan yang bekerja pada status sakit. 2. Bahwa apabila melalui penelitian sumber tersebut diketahui, maka umumnya dapat disimpulkan bahwa timbulnya kejadian penyakit menular melalui makanan itu disebabkan dari tenaga pengolah makanan yang bekerja secara ceroboh dan kurang hatihati atau masa bodoh. Pengolah harus memenuhi syarat kesehatan diantaranya : harus berbadan sehat dengan mempunyai surat keterangan kesehatan.

Pemeliharaan kebersihan penjamah makanan, penanganan makanan secara higienis dan higiene perorangan dapat mengatasi masalah kontaminasi makanan. Dengan demikian kebersihan penjamah makanan adalah sangat penting untuk diperhatikan karena merupakan sumber potensial dalam mata rantai perpindahan bakteri ke dalam makanan sebagai penyebab penyakit. Menurut Depkes RI (2016), peran penjamah makanan sangat penting karena merupakan salah satu faktor dalam penyediaan makanan/minuman yang harus memenuhi syarat. Higiene perorangan dan perilaku sehat penjamah makanan harus diperhatikan. Seorang penjamah makanan harus berpedoman bahwa sanitasi lingkungan merupakan pandangan hidupnya serta menyadari akan pentingnya sanitasi makanan, higiene perorangan mempunyai kebiasaan bekerja, minat maupun perilaku sehat.

Bakteri ialah makhluk hidup yang sangat kecil yang hidup dan dapat membahayakan kesehatan, yang tidak bisa dilihat oleh mata tanpa bantuan alat mikroskop/alat pembesar. Ukuran tiap bakteri kurang lebih 1 inci yang didalamnya mengandung kurang lebih 25.000 bakteri. Bakteri merupakan makhluk hidup yang terdapat dimana-mana (udara, di tanah, dalam tubuh). Bakteri Escherichia coli adalah salah satu jenis spesies utama bakteri gram negatif, berbentuk batang pendek (kokobasik) ditemukan oleh Theodor Escherich (tahun 2015). Escherichia coli dapat bertahan hingga suhu $60^{\circ} \mathrm{C}$ selama 15 menit atau pada $55^{\circ} \mathrm{C}$ selama 60 menit. Hidup pada tinja dan menyebabkan masalah kesehatan pada manusia, seperti diare, muntaber serta masalah pencernaan lainnya.

Mekanisme pemindahan bakteri kedalam makanan secara garis besar sebagai berikut (Janie, 2016), mekanisme pencemaran dari tubuh penjamah makanan, sebagaimana diketahui kulit kita tidak pernah bebas dari bakteri, dalam populasi mikroba ini terdapat pula mikroba patogen yang berpotensi menimbulkan berbagai penyakit perut (gastroenteritis) melalui makanan. Secara umum flora bakteri yang terdapat pada kulit manusia antara lain, staphylococcus epider dan staphylococcus aureus. Bakteri ini dapat berkembang biak dalam makanan dan membentuk toksin dan dapat menimbulkan keracunan makanan. Bakteri E. coli terdiri beberapa jenis dan sebagian besar di antaranya tidak berbahaya. Itu artinya bahwa hanya segelintir jenis bakteri E. coli yang dapat merugikan kesehatan (Suswito, 2015).

Beberapa, seperti E. Coli tipe O157:H7, dapat mengakibatkan keracunan makanan yang serius pada manusia yaitu diare berdarah karena eksotoksin yang dihasilkan bernama verotoksin. Toksin ini bekerja dengan cara menghilangkan satu basa adenin dari unit 28S rRNA, sehingga menghentikan sintesis protein. Sumber bakteri ini contohnya adalah daging yang belum masak, seperti daging hamburger yang belum matang. E Coli yang tidak berbahaya dapat menguntungkan manusia dengan memproduksi vitamin $\mathrm{K}_{2}$, atau dengan mencegah bakteri lain di dalam usus. E. coli banyak digunakan dalam teknologi rekayasa genetika (Suastri, 2017).

Sebagai vektor untuk menyisipkan gen-gen tertentu yang diinginkan untuk dikembangkan. E. coli dipilih karena pertumbuhannya sangat cepat dan mudah dalam penanganannya. Manusia dapat terinfeksi bakteri E.Coli melalui makanan atau air yang terkontaminasi. Masa inkubasi dari 
bakteri adalah 3-4 hari setelah berbagai gejala pencernaan terjadi. Gejala yang terjadi dapat bervariasi mulai dari diare, demam ringan, sampai diare berat tanpa demam. Tetapi pada kasus yang jarang terjadi, khususnya pada anak di bawah 5 tahun dan manula, gejala infeksi ini dapat sangat serius hingga menyebabkan sindroma uremia hemolitik yang dapat berakhir menjadi gagal ginjal, perdarahan dan berbagai masalah syaraf. tingkat kematian yang disebabkan penyakit tersebut sebesar 3-5\% (Purnawi, 2015).

Ilmu ekonomi arus utama, konsep pasar adalah setiap struktur yang memungkinkan pembeli dan penjual untuk menukar jenis barang, jasa dan informasi. Pertukaran barang atau jasa untuk uang disebut dengan transaksi. Pasar terdiri dari semua pembeli dan penjual yang baik yang memengaruhi harganya. Pengaruh ini merupakan studi utama ekonomi dan telah melahirkan beberapa teori dan model tentang kekuatan pasar dasar penawaran dan permintaan. Ada dua peran di pasar, pembeli dan penjual. Pasar memfasilitasi perdagangan dan memungkinkan distribusi dan alokasi sumber daya dalam masyarakat. Pasar mengizinkan semua item yang diperdagangkan untuk dievaluasi dan harga. Sebuah pasar muncul lebih atau kurang spontan atau sengaja dibangun oleh interaksi manusia untuk memungkinkan pertukaran hak (kepemilikan) jasa dan barang (Titian, 2015).

Pasar tradisional merupakan tempat bertemunya penjual dan pembeli serta ditandai dengan adanya transaksi penjual pembeli secara langsung dan biasanya ada proses tawar-menawar, bangunan biasanya terdiri dari kios-kios atau gerai, los dan dasaran terbuka yang dibuka oleh penjual maupun suatu pengelola pasar. Kebanyakan menjual kebutuhan sehari-hari seperti bahan-bahan makanan berupa ikan, buah, sayur-sayuran, telur, daging, kain, pakaian barang elektronik, jasa dan lain-lain. Selain itu, ada pula yang menjual kue-kue dan barang-barang lainnya. Pasar seperti ini masih banyak ditemukan di Indonesia, dan umumnya terletak dekat kawasan perumahan agar memudahkan pembeli untuk mencapai pasar. (Profil Pasar Tradisiona, 2017).

Berdasarkan survey awal yang dilakukan peneliti terhadap pedangang taradisional di kota baringin Sibolga kota
Tahun 2018 terdapat, 1. Dari 17 orang pedagang tradisional yang ada di kota sibolga kota baringin, terdapat 10 orang yang tidak memperdulikan higene makanannya dibuktikan dari lingkungan jualan yang kotor dan bau, tidak menutup tempat makanan agar terhindar dari debu dan kotoran. 2. Dari 17 orang pedagang tradisional yang ada di kota sibolga kota baringin, terdapat 9 orang yang tidak memperdulikan perilaku penjamah makanannya dibuktikan dari tidak mencuci tangan sesudah menjamah makanan. 3. Dari 17 orang pedagang tradisional yang ada di kota sibolga kota baringin, terdapat 12 orang yang tidak mengerti terhadap terkontaminasi esceriasis coli dapat timbul dari jajanan tradisional. Berdasarkan latar belakang di atas, penulis tertarik untuk mengetahui hubungan sikap penjamah makanan dengan hygine sanitasi jajanan tradisional di pasar tradisional Kota Sibolga Tahun 2018.

\section{METODE PENELITIAN}

Penelitian ini menggunakan penelitian kuantitatif dengan desain penelitian deskriptif korelasi dengan uji Pearson Corelasi. Penelitian menggunakan desain untuk memberikan bukti dan menganalisis sikap penjamah makanan dengan Hygine jajanan tradisional. Sikap penjamah makanan sebagai variabel dependen dan Hygine jajanan tradisional sebagai variabel independent. Lokasi penelitian ini adalah dilakukan di Pasar Tradisional Kota Sibolga yang pasar tradisionalnya buka tiap hari. Ada sekitar 31 orang pedagang yang berjualan untuk menjual makanannya. Setting penelitian adalah tempat dan kondisi atau keadaan dimana studi penelitian yang sebenarnya berlangsung (Polit \& Beck, 2012). Pemilihan lokasi didasarkan pada pertimbangan belum pernah dilakukan penelitian sejenis dan ditentukan masalah Hygine jajanan tradisional di pasar tradisional kota sibolga.

Waktu penelitian dimulai dari penyusunan proposal penelitian sampai penyusunan hasil penelitian yaitu bulan September tahun 2018. Pengambilan sampel dalam penelitian ini adalah dengan menggunakan Total Sampling yaitu seluruh populasi diambil unntuk menjadi responden penelitian yang berjumlah 31 orang. 


\section{HASIL PENELITIAN \\ Karakteristik Responden}

Pengumpulan data yang telah dilakukan di Pasar Tradisional Kota Sibolga dari tanggal 28 September sampai dengan 5 November 2018, dengan jumlah sampel sebanyak 31 orang yang bekerja sebagai penjual makanan jajanan tradisional di pasar tradisional Kota Sibolga. Bahwa dari 31 pedagang tradisional kota sibolga berdasarkan umur mayoritas berusia 23-33 tahun sebanyak 15 orang $(48,4 \%)$, berdasarkan jenis kelamin mayoritas berjenis kelamin perempuan sebanyak 22 orang (71\%), berdasarkan pekerjaan mayoritas wiraswasta sebanyak 31 orang $(100 \%)$, berdasarkan lama bekerja sebagai pedagang mayoritas 1-5 tahun sebanyak 14 orang $(45,2 \%)$ berdasarkan pendidikan terakhir mayoritas berpendidikan SMA sebanyak 16 orang $(51,6 \%)$.

\section{Analisa Univariat}

Hasil penelitian distribusi frekuensi berdasarkan sikap penjamah makanan yang diteliti adalah sebagai berikut: Bahwa dari 31 mayoritas menyatakan sikap penjamah makanan yang dilakukan pedagang adalah cukup baik yaitu sebanyak 14 orang $(45,2 \%)$ dan minoritas sikap penjamah makanan dilakukan pedagang adalah kurang baik 7 orang $(22,6 \%)$. Hasil penelitian distribusi frekuensi berdasarkan hygine sanitasi yang diteliti adalah sebagai berikut: Bahwa 31 mayoritas menyatakan hygene sanitasi baik yaitu 22 orang $(71,0 \%)$ dan minoritas hygene sanitasi buruk yaitu sebanyak 9 orang $(29,0 \%)$.

Sebelum dilakukan variansi untuk menguji hipotesis yang diajukan maka terlebih dahulu akan dilakukan uji pra syarat atau uji asumsi (Hadi, 2000) yaitu uji normalitas pada variabel sikap penjamah makamanan dan hygine sanitasi. Uji normalitas bertujuan untuk mengetahui apakah distribusi data dengan menggunakan berdistribusi normal dengan nilai angka signifikan $\mathrm{p}>0,05$. Maksud asumsi normalitas adalah variabel $\mathrm{Y}$ berdistribusi normal untuk tiap pengamatan variabel $\mathrm{X}$ yang dapat diketahui dari plot residual. Apakah data menyebar di sekitas garis diagonal dan mengikuti arah garis diagonal maka model regresi memenuhi asumsi normalitas atau apabila angka signifikan $\mathrm{p}>0,05$ maka data berdistribusi normal.
Uji normalitas sebaran dilakukan pada variabel sikap penjamah makanan dan hygene sanitasi. Analisis untuk uji normalitas ini menggunakan teknik Kolmogorov-Smirnov. Hasil uji normalitas untuk variabel sikap penjamah makanan dan hygene.

\section{Analisa Bivariat}

Akan ditampilkan hasil uji statistik untuk hubungan sikap penjamah makanan dengan hygene sanitasi di pasar Tradisional Kota Sibolga. Tentang uji pearson corelation untuk mengetahui hubungan variabel sikap penjamah makanan dengan hygene sanitasi diperoleh Pearson Correlation diperoleh hasil adalah $-0,369<0,05$ artinya ada hubungan antara sikap penjamah makanan dengan hygene sanitasi. Hasil dari uji pearson corelation terhadap nilai signifikan hubungan variabel sikap penjamah makanan dengan hygene sanitasi diperoleh diperoleh hasil adalah $0,041<0,05$ artinya ada hubungan antara sikap penjamah makanan dengan hygene sanitasi. Tingkat hubungan berada pada korelasi sedang dan berada pada hubungan negatif.

Tabel 1.

Hasil Uji Korelasi Bivariat Sikap Penjamah Maknan dengan Hygene Sanitasi di Pasar Tradisional Kota Sibolga $(n=31)$.

\begin{tabular}{|c|c|c|c|}
\hline \multicolumn{4}{|c|}{ Correlations } \\
\hline & & $\begin{array}{l}\text { Sikap } \\
\text { Penjamah } \\
\text { Makanan }\end{array}$ & $\begin{array}{l}\text { Hygine } \\
\text { Sanitasi }\end{array}$ \\
\hline \multirow{4}{*}{$\begin{array}{l}\text { Sikap } \\
\text { Penjamah } \\
\text { Makanan }\end{array}$} & Pearson & 1 & -.369 \\
\hline & Correlation & & \\
\hline & $\begin{array}{l}\text { Sig. } \\
\text { tailed) }\end{array}$ & & .041 \\
\hline & $\mathrm{N}$ & 31 & 31 \\
\hline \multirow{3}{*}{$\begin{array}{l}\text { Hygine } \\
\text { Sanitasi }\end{array}$} & Pearson & -.369 & 1 \\
\hline & $\begin{array}{l}\text { Correlation } \\
\text { Sig. (2- } \\
\text { tailed) }\end{array}$ & .041 & \\
\hline & $\mathrm{N}$ & 31 & 31 \\
\hline
\end{tabular}

\section{PEMBAHASAN \\ Karakteristik Responden}

Penjamah makanan adalah orang yang secara langsung berhubungan dengan makanan dan peralatan mulai dari tahap persiapan, pembersihan, pengolahan, pengangkutan, 
sampai dengan penyajian. Untuk memperoleh kualitas makanan yang baik perlu diperhatikan dan diawasi mengenai pengetahuan, sikap dan perilaku tenaga pengolah. Tujuannya untuk menghindari terjadinya penularan penyakit melalui makanan yang disebabkan tenaga pengolah makanan (Nugroho, 2017). Bahwa dari 31 pedagang tradisional di kota sibolga berdasarkan umur mayoritas berusia 23-33 tahun sebanyak 15 orang $(48,4 \%)$ dan minoritas 50-59 tahun sebayak 2 orang (6,5\%).

Faktor usia terkait dengan kejadian perilaku yaitu terjadinya beberapa perubahan fisiologis. Selain itu, usia 23-33 tahun, merupakan usia produktif dalam bekerja. Hasil penelitian yang dilakukan Chaningsih (2018) di Fakultas UGM (universitas Gajah Mada) didapat hasil bahwa angka kuman yang tidak memenuhi syarat terbanyak ada pada responden pendidikan SMP $(81,8 \%)$, sedangkan yang memenuhi syarat terbanyak ada pada responden dengan pendidikan SD $(42,9 \%)$. Hasil uji statistik menunjukkan bahwa tidak ada hubungan yang signifikan antara variable pendidikan dengan angka kuman karena nilai $\mathrm{p}$ lebih besar dari batas toleransi $(\mathrm{p}>0,05)$.

Jumlah wanita umumnya lebih banyak dari jumlah laki-laki, terbukti dari survey yang dilakukan oleh WHO pada tahun 2016 jumlah penduduk wanita lebih banyak dari laki-laki dengan perbandingan 1 banding 3 (1: 3 ). Berdasarkan jenis kelamin yang terdapat dalam penelitian ini mayoritas berjenis kelamin perempuan sebanyak 22 orang (71\%), dan minoritas laki-laki sebanyak 9 orang (29\%). Secara tersirat memang penelitian ini sesuai dengan teori yang ada. Tetapi, apabila ditelaah lebih lanjut, maka dapat diketahui bahwa wanita sebagian responden perempuan dalam penelitian ini telah masuk pada pekerjaan yang tidak memerlukan tenaga kuat, seperti kebanyakan yang dilakukan oleh lakilaki contohnya mengangkat beban berat pada saat bekerja. (Kumar, et al., 2018).

Faktor yang mempengaruhi prilaku penjamah makanan adalah pendidikan. Dari tabel diatas responden pada penelitian ini menunjukkan bahwa sebagian besar dari mereka mempunyai latar belakang pendidikan Berdasarkan Pendidikan Terakhir, mayoritas responden berpendidikan SMP (sekolah menengah pertama) yaitu 6 orang $(40 \%)$, minoritas berpendidikan DIII, yaitu 2 orang
(13\%). Menurut A Wawan dan Dewi M bahwa pendidikan semakin tinggi maka akan semakin banyak pengetahuan yang dimiliki tentang menjaga hygine dalam pengelolaan makanan. Responden pada penelitian ini menunjukkan sebagian besar sekolah dasar karena itulah masih banyak responden yang belum mengetahui penanganan pegolahan makanan yang baik dan yang benar.

Tingkat pendidikan responden berhubungan dengan perilaku penjamah makanan dengan hygine (> 0.05). Fenomena ini karena pendidikan yang tinggi tidak mempengaruhi kebiasaan pencucian peralatan makan yang higienis. Hal ini dapat dilihat dari jumlah responden yang berpendidikan tinggi tetapi 75,0 \% hasil uji angka kuman tidak memenuhi syarat, sedangkan yang berpendidikan rendah hanya $57,0 \%$ hasil uji angka kuman tidak memenuhi syarat, sperti diketahui tingkat pendidikan yang dimiliki oleh seseorang tidak selalu berbanding lurus dengan pekerjaan yang dihadapinya. Itu artinya bahwa setiap orang berharap dengan pekerjaan baru harus selalu banyak melakukan adaptasi dengan pekerjaan tersebut. Tetapi teori Green menyatakan bahwa pendidikan terbasuk faktor predisposisi dalam perubahan perilaku seseorang. Pengetahuan mengenai kesehatan yang dimiliki oleh penjamah makanan dapat meningkatkan keamanan makanan yang diolahnnya seperti tingkat penyehatan makanan itu sendiri. Berdasarkan uraian di atas dapat dikemukakan bahwa ada ketidak sesuaian antara teori dan hasil penelitian yang diperoleh merupakan kelemahan penelitian selanjutnya.

Perilaku penjamah makanan pada warung makanan di Desa Caturtunggal sebagian besar $(65 \%)$ termasuk dalam kategori sedang, hal ini sesuai dengan latar belakang pendidikan responden yang sebagian besar (45\%) berpendidikan SLTA. Berdasarkan hasil uji kualitas bakteriologis didapatkan hasil 26 responden yang berprilaku sedang sebanyak $73,1 \%$ hasil uji langka kuman permukaan piring tidak memenuhi syarat, hal ini bisa terjadi karena meskipun sebagian besar.

\section{Sikap Penjamah Makanan}

Sikap penjamah makan menunjukkan bahwa dari 31 mayoritas menyatakan sikap penjamah makanan yang dilakukan pedagang adalah cukup baik yaitu sebanyak 14 orang 
$(45,2 \%)$ dan minoritas sikap penjamah makanan dilakukan pedagang adalah kurang baik 7 orang $(22,6 \%)$. Hasil penelitian lain menyebutkan sikap penjamah makanan pada warung makan di Desa Caturtunggal sebagian besar $(65 \%)$ termasuk daam kategori sedang, hal ini sesuai dengan latar belakang pendidikan responden yang sebagian besar (45\%) berpendidikan SLTA. Berdasarkan berdasarkan uji kualitas bakteriologis didapat dari 26 responden yang berprilaku sedang sebanyak $73,1 \%$ hasil uji angka kuman permukaan piring tidak memenuhi syarat, hal ini bisa terjadi karena meskipun sebagian besar pendidikan responden adalah SLTA tetapi berdasarkan hasil wawancara didapat pengakuan bahwa responden belum pernah mengikuti kursus tentang hygiene sanitasi makanan dan belum pernah mendapat pembinaan serta pengawasan dari instansi terkait, sehingga sikap yang kurang baik tersebut disebabkan oleh ketidak tahuan penjamah makanan pada peraturan dan persyaratan yang mengatur tentang hygiene sanitasi makanan di pasar tradisional. Untuk meningkatkan kualitas makanan yang disajikan maka perlu adanya peneningkatan pengetahuan melalui pemberian/kursus dan praktik lapangan terhadap pengelola, penyaji makanan serta para Pembina dan pengawas kebersihan makanan di lapangan. Selain itu, peningkatan pengetahuan penjamah makanan melalui pemberian pelatihan/kursus dapat menurunkan angka kesakitan dan kematian karena makanan.

Sikap penjamah makanan dari teori dan pengalaman yang telah dilakukan individu bersangkutan. Sebagai contoh orang dengan latar belakang pendidikan tinggi yang bukan kesehatan pasti akan berbeda dalam menguasai perihal kesehatan dibandingkan dengan kader kesehatan yang latar belakang pendidikan rendah. Akan tetapi pendidikan yang tinggi tersebut akan lebih mempermudah individu bersangkutan untuk melakukan analisis terkait kondisi yang dihadapi, dalam hal ini tentang hygiene dan sanitasi makanan jajanan tradisional.

\section{Hygine Sanitasi}

Berdasarkan hasil penelitian yang dilakukan dalam penelitian ini diketahui bahwa dari 31orang mayoritas menyatakan hygene sanitasi baik yaitu 22 orang $(71,0 \%)$ dan minoritas hygene sanitasi buruk yaitu sebanyak 9 orang (29,0\%). Menurut Perry dan Potter, personal hygiene adalah suatu tindakan untuk memelihara kebersihan dan kesehatan seseorang untuk kesejahtraan fisik dan psikis. Kebersihan adalah suatu keadaan yang terbatas dari kotoran dan mikroorganisme patogen, dalam hygiene ada pengertian tentang perawatan yang secara positif yang mempengaruhi kesejahtraan manusia. Kesehatan berhubungan dengan tingkat kesejahtraan jasmani, rohani dan sosial.

Tujuan umum dari Hygiene adalah untuk mencegah timbunya penyakit. Pemeliharaan hygiene perorangan diperlukan untuk kenyamanan individu, keamanan dan kebersihan. Seperti pada orang sehat mampu memenuhi kebutuhan kesehatannya sendiri, pada orang yang sakit atau kebersihan fisik memerlukan perawatan praktik kesehatan yang rutin. Sanitasi tempat pegolahan makanan dapur harus bersih, dan hanya digunakan untuk membersihkan makanan, semua permukaan sifatnya harus mudah dibersihkan. Hasil penelitian yang dilakukan oleh Sahrizal tahun 2017 di lakukan di Desa Batoh Kecamatan Lueng Bata Banda Aceh tentang hygiene sanitasi penjamah makananterhadap kandungan bakteri E. Coli, didapat, dengan kategori memenuhi syarat $75 \%$, hal ini dikarenakan lokasi tempat yang bersih dan tidak licin, air brsih yang cukup, pembuangan air limbah mengalir dan ventiasi yang berfungsi baik. Sedangkan $25 \%$ yang tidak memenuhi syarat sanitasi tempat pengolahan makanan, disebabkan karena dinding dan langit-langityang tidak bersih yang kamar mandi yang dekat dengan dapur.

\section{Analisa Bivariat

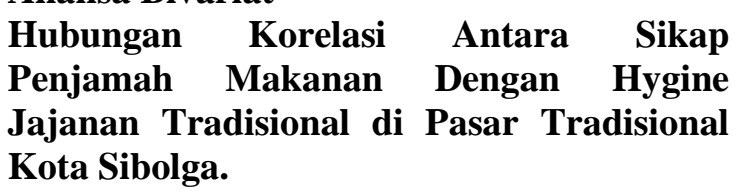

Berdasarkan Korelasi antara sikap penjamah makanan dengan hygiene jajanan tradisional di pasar tradisioanal Kota Sibolga, menggunakan uji pearson corelation untuk mengetahui hubungan variabel sikap penjamah makanan dengan hygene sanitasi diperoleh nilai Pearson Correlation adalah $-0,369<0,05$ artinya ada hubungan antara sikap penjamah makanan dengan hygene sanitasi. Hasil dari uji pearson corelation terhadap nilai signifikan 
hubungan variabel sikap penjamah makanan dengan hygene sanitasi diperoleh diperoleh hasil adalah $0,041<0,05$ artinya ada hubungan antara sikap penjamah makanan dengan hygene sanitasi. Tingkat hubungan berada pada korelasi sedang dan berada pada hubungan negatif.

$\begin{array}{llrr}\text { Hasil penelitian } & \text { yang } & \text { dilakukan } \\ \text { Chaningsih } & (2018) \text { di } & \text { Fakultas } & \text { UGM } \\ \text { (universitas Gajah } & \text { Mada) } & \text { dengan } \\ \text { ditemukannya } & \text { hubungan yang } & \text { signifikan } \\ \text { antara perendaman } & \text { dengan } & \text { kualitas }\end{array}$
bakteriologis kemungkinan disebabkan sebagian besar responden (55\%) menyatakan tidak pernah melakukan perendaman, sedangkan $45 \%$ responden menyatakan melakukan perendaman pada alat makan piring. Perendaman perlu dilakukan karena pada perendaman yang dimaksud untuk memberi kesempatan peresapan air ke dalam sisa makanan yang menempel dan mengeras sehingga menjadi lebih muda untuk membersihkan atau terlepas dari permukaan alat.

Sebagian besar responden dalam penelitian ini tidak memakai celemek dan tutup kepala karena responden merasa pakaian dan tangan mereka sudah bersih. Apabila memakai celemek dan tutup kepala rasanya tidak nyaman dan ada yang terganggu ketika memasak. Praktek menggarauk anggota badan saat mengelolah makanan sebaiknya tidak dilakukan. Tangan responden tidaklah steril meskipun pada awalnya dia mencuci tangan, bahkan dengan sabun sekalipun. Sebab selain memegang makanan, sesekali tangan responden memegang benda lain seperti uang. Kuman yang menempel pada uang dapat berpindah pada tangan responden. Kuman dapat ditemukan ditangan manusia yang terakomulasi di bawah kuku jari tangan penjamah makanan. Mayoritas dari kuman itu sulit dihilangkan meskipun dibersihkan berkali-kali (Depkes RI, 2017).

Selain itu sikap dan praktek penjamah makanan dalam personal hygiene juga masih kurang. Responden tidak selalu mencuci tangannya sebelum menjamah makanan karena biasanya responden hanya membersihkan tangan dengan lap atau mencuci tangan bersama dengan mencuci peralatan makan dan masak. Apalagi disaat warung sedang ramai maka responden tidak sempat membersihkan tangannya. Untuk mendukungnya maka fasilitas tempat cuci tangan berupa ember atau bak dengan air mengalir seharusnya perlu disediakan (Ermayani, 2015).

\section{KESIMPULAN}

Penelitian ini terhadap 31 orang responden yang bekerja sebagai pedagang tradisional di pasar tradisional kota sibolga dapat ditarik kesimpulan sebagai berikut : Bahwa dari 31 pedagang tradisional kota sibolga berdasarkan umur mayoritas berusia 23-33 tahun sebanyak 15 orang $(48,4 \%)$, berdasarkan jenis kelamin mayoritas berjenis kelamin perempuan sebanyak 22 orang $(71 \%)$, berdasarkan pekerjaan mayoritas wiraswasta sebanyak 31 orang $(100 \%)$, berdasarkan lama bekerja sebagai pedagang mayoritas 1-5 tahun sebanyak 14 orang $(45,2 \%)$ berdasarkan pendidikan terakhir mayoritas berpendidikan SMA sebanyak 16 orang $(51,6 \%)$.

Berdasarkan sikap penjamah makanan menunjukkan bahwa dari 31 orang mayoritas menyatakan sikap penjamah makanan yang dilakukan pedagang adalah cukup baik yaitu sebanyak 14 orang $(45,2 \%)$ dan minoritas sikap penjamah makanan yang dilakukan pedagang adalah kurang baik 7 orang $(22,6 \%)$. Berdasarkan hygine menunjukkan bahwa 31 orang mayoritas menyatakan hygene sanitasi baik yaitu 22 orang $(71,0 \%)$ dan minoritas hygene sanitasi buruk yaitu sebanyak 9 orang $(29,0 \%)$.

Berdasarkan Korelasi antara sikap penjamah makanan dengan hygiene Tentang uji pearson corelation untuk mengetahui hubungan variabel sikap penjamah makanan dengan hygene sanitasi diperoleh Pearson Correlation diperoleh hasil adalah -0,369 < 0,05 artinya ada hubungan antara sikap penjamah makanan dengan hygene sanitasi. Hasil dari uji pearson corelation terhadap nilai signifikan hubungan variabel sikap penjamah makanan dengan hygene sanitasi diperoleh diperoleh hasil adalah $0,041<0,05$ artinya ada hubungan antara sikap penjamah makanan dengan hygene sanitasi. Tingkat hubungan berada pada korelasi sedang dan berada pada hubungan negatif.

\section{SARAN}

Berdasarkan hasil penelitian diatas dapat dikemukakan beberapa saran sebagai berikut : Bagi Institusi Pendidikan, Penelitian ini hendaknya berguna bagi pendidikan, dan 
disarankan dilakukan penelitian yang sama dengan jumlah sampel yang lebih besar dan di tempat yang berbeda. Bagi Tempat Penelitian, Agar dapat meningkatkan pemberian informasi mengenai perilaku penjamah makanan dan hygine di pasar tradisiona di kota sibolga. Bagi Responden, Diharapkan bagi para responden agar menerapkan perilaku yang baik dan hygiene yang baik juga, agar makanan yang disajikan terhindar dari penyakit yang dapat muncul di kemudian hari.

\section{REFERENSI}

Amzar, C. Y. (2015). Buku Kesehatan Lingkungan. (Edisi 2). Jakarta: UI Press.

Chaningsih, A. F. (2018). Mutu Pelayaan Kesehatan: Perspektif Internasional. Jakarta: EGC.

Depkes. (2013). Kebijakan Kesehatan. Yogyakarta: Media ilmu.

Ermayani. (2015). Faktor Kontaminasi Bakteri Pada Jajanan Makanan Diakses dari : //www.

Kompas.co.id/kesehatan/0709/05/1907 02.htm/indeks/dibuka tanggal 18 Mei 2015.

Budiarto, Eko. (2007). Biostatistik. Jakarta: EGC

Fardiaz, (2015). Indikator Indonesia Sehat 2010 dan Pedoman Penetapan Indikator Provinsi Sehat dan Kabupaten/Kota Sehat, Departemen Kesehatan. Jakarta.

Haninegoro, Sri Rezeki S. (2018). Pendokumentasian yang baik. Jakarta : Badan Penerbit Ikatan Dokter Indonesia.

Jamie. (2015). Buku Kesehatan Masyarakat, Edisi ke-4. Jakarta: Gunung Agung.

Marianti. (2017). Buku Kesehatan Masyarakat. Jakarta : Salemba Medika.

Mubarak, W. (2007). Kesehatan Masyarakat. Jakarta : Rineka Cipta

Mukono. (2017). Buku Kesehatan Masyarakat. Jakarta : EGC.

Notoadmojo, Soekidjo. (2007). Metodologi Penelitian Kesehatan. Edisi 2. Jakarta: Rineka Cipta.

Nugroho (2018). Pengantar Ilmu Kesehatan Masyarakat I. Jakarta : Salemba Medika.
Profil Pasar Tradisional. (2017). Peningkatan Produktifitas. Jakarta: Bumi Aksara.

Purnawi. (2015). Pedoman Dalam Kesehatan makanan. Jakarta: Badan Penerbit Ikatan Dokter Indonesi.

Sondang P. Siagian. (2002). Teori Motivasi dan Aplikasinya. Jakarta: Bina Aksara

Supartini, Yupi. (2004). Buku Ajar Konsep Dasar Kesehatan. Jakarta: EGC.

Uno, Hamzah B. (2008). Teori Motivasi dan Pengukurannya: Analisis di Bidang Pendidikan. Jakarta: Bumi Aksara. 